\title{
Exemplary influences and Augustus' pernicious moral legacy
}

Rebecca Langlands

\section{(This is an online pre-publication of an article which will be published in Roy Gibson and Tristan Power (eds.) Suetonius the Biographer: Studies in Roman Lives, OUP 2014)}

\section{Introduction: Remembering Augustus' marriage}

According to Suetonius, Augustus' last words were to his wife: 'Livia, remember our marriage!' For David Wardle, who reads Suetonius' account of Augustus' death as a portrayal of a paradigmatic emperor, this injunction, naturally enough, appears characteristic of Augustus' concern for the institution of marriage: 'Livia is to remember neither love, nor him, but their marriage, the institution which the moral laws that bore his name had been designed to protect. As Gugel suggests, no words could be more characteristic of Augustus who had struggled so hard to uphold the integrity of the family'. 'Wardle is right that Suetonius' death scene portrays Augustus in a generally positive light. However, the irony of this death-bed concern to memorialize his marriage would not have been lost on Suetonius' readers, any more than the ironies of the tradition surrounding his life were lost. ${ }^{3}$ His marriage was indeed remembered by posterity, not, however, so much for its longevity and love, but as the marriage that began with the theft of another man's pregnant wife. Suetonius' brief reference at 62.2 sums it up: 'And immediately he stole Livia Drusilla from her marriage with Tiberius Nero even though she was pregnant...' (ac statim Liuiam Drusillam matrimonio Tiberi Neronis et quidem praegantem abduxit, 62.2). ${ }^{4}$ Read in the light of allusions found in Suetonius' later Lives, the irony becomes mordant; later emperors remember this theft above all of Augustus' achievements, and model their own behaviour upon it. Caligula issues a public proclamation citing Augustus (with Romulus) as a precedent for his seizure of C. Piso's bride - appropriately named Livia ${ }^{5}$ - on her wedding day; with this immoral and tyrannical act he claims to be following 'the exemplum of Augustus' (exemplo... Augusti, Calig. 25.1). Later, Domitian clearly echoes Augustus' precedent with the theft of Aelius Lamia's bride, Domitia Longina, whom he calls Augusta, in an echo of the title Augustus bestowed on Livia in his will (Dom. 3.1, an allusion to Aug. 69.1, cf. 101.2). The irony lurking in Augustus' valediction, and also in the interpretation of it by Gugel via Wardle, goes to the heart of Suetonius' portrayal of Augustus. He was a man of extraordinary achievements, who 'struggled' nevertheless to control the sexual morality of his

\footnotetext{
${ }^{1}$ Suet. Aug. 99.1 "Liuia, nostri coniugii memor uiue!"

${ }^{2}$ Wardle (2007) 458, citing Gugel (1977) 97.

${ }^{3}$ McGinn (1998) 83, n. 140.

${ }^{4}$ Cf. Suet. Aug. 69.1; Tib. 4; Calig. 25; Tac. Ann. 1.10, 5.1.2; see Flory (1988) on the tradition surrounding this story, especially 343 n. 1 for the sources.

${ }^{5}$ Cf. Wardle (1994) 231: “The nomen Livia, which only Suetonius records, is probably an error." Or a deliberate allusive tweak?
} 
subjects, of his family and of posterity. He embodies the limitations of even the most powerful and influential of human beings when it comes to foreseeing the future significance and outcomes of their actions in the face of destiny.

It is a commonplace that, for Suetonius, Augustus is the paradigmatic good emperor, with whom emperors in subsequent Lives are compared and found wanting, and whom subsequent emperors strive in various ways to emulate. ${ }^{6}$ As Erik Gunderson discusses in this volume, Suetonius also represents Augustus as an emperor who is particularly aware of the power of exempla to influence moral behaviour, and is concerned both to deploy traditional exempla as part of his moral reforms and to present himself and his family as fresh exempla for the new imperial age. ${ }^{7}$ In his life of Augustus, Suetonius presents us with a man who puts enormous effort into shaping his own life, the behaviour of other people, and the future, with aspirations to set up stable foundations for an enduring and beneficial empire (see especially Aug. 28 on his aspirations for an enduring principate, Aug. 101 for the careful provision for the future found in his will). However, for all his achievements, and for all his efforts, Augustus, as I shall argue and as the irony of his final words suggest, is represented by Suetonius as a man whose legacy is, after all, not within his control. Even the apparent admiration of Suetonius expressed at Aug. 28 hints very delicately at the dislocation between intention and outcome, when he comments briefly and ambiguously on Augustus' (crucial!) decision not to restore the republic, but to continue as sole ruler of Rome: 'it is doubtful whether the outcome or the intention was better' (dubium euentu meliore an uoluntate, Aug. 28.1). This chapter ends with Suetonius' judgement on Augustus' achievements which acknowledges the limits of human capacity to predict and control the future: 'He made the state safe, for the future too, as far as human foresight is able provide' (tutam vero, quantum provideri bumana ratione potuit, etiam in posterum praestitit, Aug. 28.3).

Now, Suetonius has inherited a complex tradition about Augustus, incorporating both panegyric and critical elements; this paper will argue that Suetonius deliberately organizes the contradictory elements of this tradition to tell us a rather poignant story about the great Augustus' failure to control his own exemplarity, which is also part of Suetonius' broader concern with the interrelated themes of exemplarity, hindsight, fate and the individual. Tacitus claims that dissenting voices about how Augustus' life should be interpreted broke out immediately after his death; early in the Annals he

\footnotetext{
${ }^{6}$ See Wardle (2007).

7 Suet, Aug. 31.5; 89.2; 101.4. Gunderson (in this volume) reads Suetonius as a diligent student of Augustus' teachings on exempla, who replicates Augustus' prescriptive exemplarity, while representing Tiberius as an exemplary failure. My own reading of Suetonius' treatment of Augustus' exemplarity is rather different. My own research tends to emphasise the openness of exempla to interpretation at the point of reception (see e.g. Langlands (2008)) and here I see Suetonius as providing resistance to Augustus' attempts to control exempla and monopolize their meaning. On Augustus' use of exempla and his attempts to set himself up as an exemplum for the edification of posterity see further Chaplin (2000) 173196; Kraus (2005) 194-5; Lowrie (2007).
} 
outlines the two sides of the controversy (Ann. 1.9-10). ${ }^{8}$ In Suetonius' biography, traces of this contradictory tradition are most evident in the intertweaving of Mark Antony's invective against Augustus with allusions to Augustus' own Res Gestae. ${ }^{9}$ The controversy has various points of focus, including Augustus' role in the civil wars and the proscriptions, but sexual morality - to be discussed here - is a prominent theme. On the one hand Augustus is praised for his sexual continence (Aug. 71.1), and for maintaining strict discipline within his own household (Aug. 64.2) and especially for his moral reforms, instigating a series of legislative measures designed to control the sexual behaviour of the Roman elite (Aug. 34): the Lex Julia de maritandis ordinibus in 18 BC introduced penalties for marriages between those of very different status and incentives for marriage and child-rearing, while the Lex Julia de adulteriis introduced strict punishments for adultery and other sexual misconduct; in AD 9 the Lex Papia Poppaea introduced amendments to the Lex Julia, although it is not entirely clear what these were. ${ }^{10}$ On the other hand critical voices speak out about his own adulteries and most persistently of his marriage to Livia as a theft from her previous husband, which is cast as the stereotypical behaviour of a tyrant, presumably shaped by Antony's original invective tropes. ${ }^{11}$ As Tacitus puts it: 'criticism did not hold back from his domestic affairs: he had stolen Nero's wife and ludicrously asked the priests whether it was acceptable to marry her while she was pregnant' (nec domesticis abstinebatur: abducta Neroni uxor et consulti per ludibrium pontifices an concepto necdum edito partu rite nuberet, Tac. Ann. 1.10).

It may well have been in direct response to the association that Augustus himself made between sexual morality and imperial exemplarity (as immortalized in bronze at Res Gestae 8.5) that Suetonius entwines the two throughout his biography of Augustus (see especially Aug. 31-4), and uses the motif of sexual morality to critique Augustus' attempts to institute himself and his own family as moral exempla for posterity. In this critique he is also engaging with the paradigm of imperial exemplarity as it has developed over the hundred years since Augustus' death, including the use of Augustus as a paradigm for subsequent emperors. A succession of texts over the course of that century had been promoting imperial exemplarity, beginning with the Res Gestae in AD $14^{12}$ and including the Senatus Consultum de Cn. Pisone Patre in AD 20 (esp. 123-63), ${ }^{13}$ Seneca, de Clementia in AD 55/6 (especially 1.1.6 and 1.15.3) and

\footnotetext{
8 On this tradition see Davis (1999).

${ }^{9}$ Mark Antony's invective against Augustus peppers this biography from the outset, and provides some of the colour to Suetonius' characterisation of Augustus, off-setting his largely favourable portrait (at Aug. 2, 4, 7, 10, 16, 17, 28, 68, 69, and 70; in 86 Augustus hits back with a jibe at Anthony's oratorical style). In the opening sections of the biography that deal with Augustus' family background, Suetonius sets up a complex dynamic between himself as author, and Augustus and Mark Antony, for control of Augustus' reputation. On allusions to the Res Gestae in Suet. Aug. see Baldwin (1983) 124; Cooley (2009) 50.

${ }^{10}$ Disentangling the sources on these laws is a tricky business, see Edwards (1993) 37-42; Treggiari (1991) 275-98. On the laws see: Treggiari (1991) 60-80; McGinn (1998) 70-215; there is an accessible summary at Kemezis (2007) 273-4. On the marriage laws in Suetonius see also Wallace-Hadrill (1981) and Bauman (1982).

${ }^{11}$ See Flory (1988) 384-52.

12 On which see Cooley (2009).

${ }^{13}$ On which see Cooley (1998).
} 
Pliny, Panegyricus in AD.${ }^{14}$ Christina Kraus has recently drawn attention to the potential deadening effect upon the discourse of exemplarity of such imperial appropriation: “ When history's gaze is more or less forcibly directed at the emperor - especially (but not exclusively) to the emperor functioning as positive role model - the prescriptive function of the exempla becomes dominant. The flexibility in the exempla thus being threatened or even lost, the audience's independent response to the spectacular suggestiveness of exemplarity is repressed or redirected, and its constructive use profoundly compromised." 15 There were certainly contemporary Romans who identified and resisted this tendency. ${ }^{16}$ In an analysis of the early $3^{\text {rd }}$ century historian Cassius Dio that provides a useful comparison to my own analysis of Suetonius, Adam Kemezis has suggested that Dio's treatment of Augustus' marriage laws may have been designed precisely to reclaim Augustus from his recent appropriation as an exemplum by the emperor Severus. ${ }^{17}$ Kemezis argues that Dio takes a long view which finds a way to resolve the tension between the paradigmatic and the critical aspects of the tradition by contrasting Augustus' short-term failure with his long-term success, ${ }^{18}$ drawing a distinction between 'his questionable character as an individual and his immense institutional achievement as founder of a stable state. ${ }^{19}$

A comparison between the ways they arrange the material relevant to sexual morality brings out the distinction between the approaches of Dio and Suetonius. In Dio's account, the marriage laws appear in their appropriate chronological contexts - the Lex Julia in Book 54 among the events for 18 BC and the Lex Papia Poppaea in Book 56 among those of AD 9 - and Dio emphasizes the hypocrisy of Augustus' behaviour by juxtaposing life and law and signalling the disjunction between them upfront. In Dio's account of the introduction of the Lex Julia in 18 BC, Augustus is confronted at the time with jeering accusations in the senate about past actions, and specifically his relationship with Livia, that are an embarrassment for his attempts to control the morality of others (Dio 54.16.3-5); ${ }^{20}$ this is also juxtaposed with another story about Augustus' inability to deal with the case of a man accused of marrying a woman with whom he had previously committed adultery, because of the obvious similarities with his own marriage to Livia. In Cassius Dio's account, Augustus' private life explicitly undermines his ability to control the morality of others. Although the lacuna in Cassius Dio means that the relevant passage covering AD 8 is lost, it is highly likely that it would have contained an account of the trial and banishment of the younger Julia for adultery, which would then have made this the

\footnotetext{
14 On which see Henderson (2011).

${ }^{15}$ Kraus (2005) 188.

${ }^{16}$ See for example Pliny Ep. 8.14.4-10 with discussion by Bradley (2010). Cf. Turpin (2008) on exempla in Tacitus.

${ }^{17}$ Kemezis (2007), especially page 283.

18 Ibid. 281.

${ }^{19}$ Ibid, 273.

${ }^{20}$ See Kemezis (2007) 277-8 for analysis of this passage in the context of Dio's overall message about Augustus and exemplarity.
} 
immediate context for Dio's account of Augustus' introduction of the Lex Papia Poppaea AD 9 which includes a lengthy moralizing speech from Augustus (56.1-10); this would have again underlined the hypocrisy of Augustus' moral reforms. ${ }^{21}$ Suetonius also takes a long view of the principate, but in his case the emphasis is on setting Augustus' aspirations in the context of their longer-term effects, as I shall show. In contrast to Dio, Suetonius organizes his material so as to suppress the actual chronology of events, arranging Augustus' laws and his domestic life under separate rubrics (at Aug. 34 and 61-69 respectively). ${ }^{22}$ Rather than juxtaposing the panegyric and critical traditions as Dio does, Suetonius to an extent separates them out so that they do not stand in direct contrast to one another. He does not emphasize the double-standards or hypocrisy of Augustus, but generates instead unchronological 'narratives' about a man whose good intentions regularly result in failure and disappointment. This pattern relates to the broader issue which bubbles under the surface of Suetonius' Lives as a whole: the extent to which an individual has the power to shape his own destiny. ${ }^{23}$ In the following sections I shall describe how this pattern of disappointed aspiration plays out in Suetonius' accounts first of the moral legislation (Aug. 34) and then of his domestic affairs (Aug. 61-9), before going to on to discuss how this pattern provides a framework for understanding Suetonius' treatment of exemplarity and his deployment of the narrative device of hindsight in the Lives.

\section{Disappointed expectation and the law}

Suetonius relates Augustus' moral legislation at chapter 34 so as to convey a sense of a strong start, with measures, powered by reforming zeal, that subsequently turn out in a variety of ways to be ineffectual, misguided, or counterproductive. In addition, when this passage is viewed in the longerterm context of the Lives as a whole, so that the influence and significance of the reforms are traced down the years, Augustus' interventions in the moral life of ancient Rome are seen to be, in the long run, detrimental or futile. ${ }^{24}$

Suetonius' account of the legislative moral reform carried out by Augustus shows him attempting to

${ }^{21}$ Kemezis (2007) 277.

${ }^{22}$ For Suetonius' careful organization of material under rubrics, especially in the Augustus, see further Hurley in this volume.

23 As Suetonius' prominent use of the themes of physiognomy (on which see Barton (1994) and Evans (1969) 51-6) and portents (see Benediktson (1996)) in his Lives show, he was especially interested in the forces of destiny that shaped an individual's life and the extent to which a man could intervene in his own destiny. Suetonius uses rubrics such as ancestry, physical description and portents not only to characterise each emperor, but also to raise unanswerable questions about why he is the way his is and why his life turned out as it did. Cf. Tatum (in this volume) on the life of Titus where the issue is placed under particular scrutiny.

${ }^{24}$ Power (in this volume) argues that the series of biographies were conceived as a whole from the beginning, and he indicates aspects of the architecture of the work within which the individual biographies are integrated. This supports the practice of reading across the lives, but even if in fact Augustus' life was written first and acts a template for the other biographies (as Hurley suggests in this volume), nevertheless the thematic resonances between the lives invite us to read them in the light of one another, as Tatum does fruitfully in this volume in his exploration of the connections between the lives of Titus and Augustus. Moreover, the chronological sequence of the biographies means that the lives of Augustus' successors to the principate are Suetonius' representations of Augustus' immediate future and legacy. 
tackle key moral problems that he has identified in Roman society: 'He redrafted laws and drew up some laws from scratch, such as sumptuary laws and laws about adultery, sexual morality, bribery and marriage among the various classes' (leges retractanit et quasdam ex integro sanxit, ut sumptuarium et de adulteriis et de pudicitia, de ambitu, de maritandis ordinibus, 34.1). Suetonius expands only upon the last law, which was designed to encourage marriage and procreation among the elite. ${ }^{25}$ This law is shown to be immediately and multiply problematic. First, 'he cannot pass it' (non potuit); it fails to win public approval and protestors force him to make amendments before it can be passed. Second, when an equestrian publicly calls for the law to be abolished, Augustus' response is to attempt to encourage the public to procreate by invoking as an exemplum Germanicus and his young family - a tableau which carries its own dark shadow of foreboding. Finally, the brief passage ends with a sentence suggesting that even once the law is passed and enforced the effect is contrary to that intended; rather than being encouraged by the legislation to marry and have children, people are inventing cunning ways of reaping the financial and legal benefits of marriage and parenthood, without actually undertaking the responsibilities:

Hanc cum aliquanto seuerius quam ceteras emendasset, prae tumultu recusantium perferre non potuit nisi adempta demum lenitaue parte poenarum et uacatione trienni data auctisque praemiis. Sic quoque abolitionem eius publico spectaculo pertinaciter postulante equite, accitos Germanici liberos receptosque partim ad se partim in patris gremium ostentauit, manu uultuque significans ne grauarentur imitari iuuenis exemplum. Cumque etiam inmaturitate sponsarum et matrimoniorum crebra mutatione uim legis eludi sentiret, tempus sponsas habendi coartauit, diuortiis modum imposuit (Ang. 34).

'This last law, since he had made emendations to it which were somewhat stricter than to the others, he was unable to pass, due to the outcry of protestors, until he had changed and eventually lessened part of the penalties, and allowed a three year gap and increased the rewards. So too, when a Roman knight was insistently demanding the abolition of the law during a public spectacle, he summoned Germanicus' children, and displayed them, some held in his own lap and some in their father's, indicating with gesture and expression that they should imitate this young man's exemplum or things would be the worse for them. When he realized that the force of the law was being evaded through betrothal to pubescent girls and through multiple remarriages, he shortened the period of betrothal and imposed restriction on divorce."

On one reading, this passage conveys a picture of Augustus as paradigmatic emperor, concerned to get things right: continually refining his legislation, responsive to the requests of his people and determined

${ }^{25}$ Lex Iulia de maritandis ordinibus of 18 BC penalised those who remained unmarried and rewards those who produce three or more children. See n.10 above. 
to set an example to them about the way life should be lived. However, just as the initial non potuit highlights Augustus' impotence, so the rest of this passage alludes to the future in a way that employs hindsight to undermine Augustus' reforms even as he devizes them, and highlights the distance between his aspirations for the future and the ways things will actually turn out. ${ }^{26}$ Meanwhile, allusions to Augustus' legislation in later Lives reactivate the ironies of Augustus' hopes for reform here. In the biography of Tiberius that follows we will discover that the pernicious effect of Augustus' moral legislation has by no means run its course. Rather, by now, innovative ways of avoiding the punishments of Augustus' legislation against adultery have been devized. Far from discouraging women of good birth from committing adultery, Suetonius informs us, the law has driven them to debase themselves further: 'Notorious women, in order to evade the punishments laid down by law - i.e. losing their matronal status and privileges - began to make the public claim to be prostitutes' (feminae famosae, ut ad euitandis legum poenas iure ac dignitate matronali exsoluerentur, lenocinium profiteri coeperant, Tib. 35.2). And the laws encouraging marriage are still being abused; Tiberius has to sack a magistrate who married a woman only to divorce her on the following day, trying to reap the rewards of marriage. ${ }^{27}$ By the time we reach Vespasian's reign we are told that Augustus' laws are no longer effective in the slightest: 'lust and luxury flourished with nothing to stop them' (libido atque luxuria coercente nullo invaluerat, Vesp. 11). ${ }^{28}$ And finally, Suetonius' biography of Domitian is regularly punctuated with references to his problematic marriage to Domitia; having followed Augustus' example in stealing her in the first place, Domitian cannot then cope with the implications of having done so in the context of Augustus' legislation (newly resuscitated by himself). He first divorces her on grounds of adultery with the actor Paris, according to Augustus's law, and then illegally remarries her (Dom. 3). He later punishes a Roman knight for the same act of remarrying a wife divorced for adultery (Dom. 8), and kills one man for joking about his theft of Domitia (10.3) and another for joking about the divorce (10.4). As the final emperor of Suetonius' batch Domitian lives out, painfully and in full consciousness of his hypocrisy, the consequences of Augustus' controversial legacy relating to marriage and sexual morality. ${ }^{29}$

In this context, the exemplum of Germanicus and his children, proudly displayed by Augustus as a salutary model of marriage and procreation, is rendered troubling: futile and naïve. This passage shows Augustus explicitly attempting to control the future morality of the Romans through imperial

\footnotetext{
${ }^{26}$ Parallels may be drawn with Herodotus' treatment of Croesus' futile expectations, in Grethlein's narratological analysis: "Time and again [Herodotus] makes Croesus focaliser and reports his unexpressed expectations as well as his utterances, often marking them as futile through anachronies." (Grethlein (2009) 161). In Suetonius' case, both explicit anachrony and the implicit anachrony of hindsight mark Augustus' expectations as futile or fragile. I explore what I argue may be direct allusions by Suetonius to Herodotus' story of Croesus and Solon below.

${ }_{27}$ Alium e quaestura removit, quod uxorem pridie sortitionem ductam postridie repudiasset. Cf. Tac. Ann. 2.8.5 and extrapolation from the case of Vistilla.

28 See further Langlands (2006) 257-63 on the complex relationship between imperial power and sexual morality in this period, and the relation to imperial exempla.

${ }^{29}$ On the hypocrisy of the gap between Domitian's private life and public correctio morum and parallels with Augustus see further Vinson (1989) 444-5.
} 
exemplarity. However, reading with our second-century, Suetonian hindsight, this episode also exposes Augustus' inability to foresee the tragic and terrible fates that we know await the family that he is offering as a model. This future will play out in the subsequent biographies: Germanicus' perilous perfection, ${ }^{30}$ his and Agrippina's fertility and their nine children, but the grim fate of the two young sons now being dandled on his and Germanicus' knees, declared public enemies by Tiberius (Calig. 7) and cruelly killed (Tib. 54.2), the emergence of a later child as imperial monster (Calig. 22), the sordid demise of another child, Agrippina the Younger, at the hands of her own son (Ner. 34.1-4), and then of the whole dynasty, in the form of Nero (Galb. 1). With hindsight, the happy family tableau that Augustus proudly displays to his people as an example of how to do family, presages nothing less than the worst excesses of the principate and the eventual downfall of the Julio-Claudians.

\section{Disappointed expectation and the family}

At Aug. 34.2 Augustus is exhorting the people of Rome to marry and have children, urging upon them, in slightly menacing fashion, the example of his own family in the shape of Germanicus and his brood. By Aug. 65.4 he is repeatedly blurting out his version of a Homeric line: 'I wish that I had never married and that I had died without offspring!'(65.4). Ironic, no? In historical reality, the trial and banishments of his daughter and granddaughter (mention of whom was enough to prompt such a cry, according to Suetonius) had already taken place when he was parading Germanicus to the public (which must have been in AD 9). However, Suetonius' biography structures them as one event, conflating the fates of the two women, as the eventual downfall of the house that dashes the earlier hopes of its paterfamilias.

Suetonius presents the fates of the Julias as a form of peripateia, and suggests that the theme here is the cruelty of fate, and its failure to reward good behaviour, in his introduction to this domestic section: 'I shall now relate his personal and domestic life, describing his behaviour and his fortune at home and among his relatives from his youth until the last day of his life', (referam nunc interiorem ac familiarem eius uitam quibusque moribus atque fortuna domi et inter suos egerit a iunenta usque ad supremum nitae diem, Aug. 61.1). As we shall see, the reference here to 'the last day of his life' is significant; it is an allusion to Solon's warning to the powerful Croesus in the Herodotean tale to call no man happy until that day is reached (Hdt.1.31-33). ${ }^{31}$

\footnotetext{
${ }^{30}$ Calig. 3-4; according to Suetonius Germanicus was so popular that he was in danger of being crushed by the crowds that surrounded him whenever he went out!

${ }^{31}$ It may be that Suetonius is alluding here more generally to the well-known topos that one should count no man happy until he is dead, rather than specifically to the Herodotean passage (see Harrison (2000) $39 \mathrm{n} .17$ for further references to the topos in Greek literature). However, there are a number of shared elements that make it reasonable to think that Suetonius may have this story as told by Herodotus in mind: the great ruler, the aspiration to found a dynasty, the perhaps excessive concern to protect his children, the sudden abandonment of fortune, the tragic fate of the children, and the foiled dynasty. (Several of these are also present in the Cadmus story of Ov. Met. 3.128-144, which also alludes to the Herodotean passage). Suetonius appears to refer to Herodotus elsewhere (Plass (1988) 152 suggests Calig. 25.3 and Nero 40), and the two authors share interests in the themes of tyranny, prophecy and the workings of fate.
} 
Like Croesus, Augustus starts his story with high hopes for his own children, especially for their moral probity - a necessity, of course, for a man who wishes to present the imperial family as an exemplum to his subjects. However, just as his moral reforms are shown to have the opposite effect from that intended, similarly, the outcomes of his strictly maintained domestica disciplina are precisely the opposite of what he hoped (Aug. 64-5); setting out to breed secluded, wool-working Lucretias, Augustus ends up producing the notorious Julias, whose falls from grace sound a strong note in his biography (see discussion of Aug. 101.3 below). The gap between intention and effect in this passage is brutal. Suetonius emphasizes the extent to which Augustus goes beyond what would have been expected of a good paterfamilias in the upbringing of his daughters, but fate takes his family in the opposite direction note the echo in the Latin of instituit (his efforts as a parent) by destituit (fortune's desertion of his family):

Filiam et neptes ita instituit, ut etiam lanificio assuefaceret uetaretque loqui aut agere quicquam nisi propalam et quod in diurnos commentarios referretur; extraneorum quidem coetu adeo prohibuit ut L. Vinicio, claro decoroque iuueni, scripserit quondam parum modeste fecisse eum, quod filiam suam Baias salutatum uenisset. (64.2)...Sed laetum eum atque fidentem et subole et disciplina domus Fortuna destituit. Iulias, filiam et neptem, omnibus probris contaminatas relegauit (65.1).

'He brought up his daughter and grand-daughters so strictly that he even trained them in woolworking and forbade them to say or do anything unless it was out in the open and could be recorded in the daily records of the household. He even prevented them from meeting with men from outside the household to the extent that he once wrote to L.Vinicius, a well-born young man of good character, that he had acted with a lack of modesty, because he had come to pay his respects to Augustus' daughter at Baiae....However, happy and confident as he was both about his offspring and about his domestic discipline, Fortune deserted him. He banished the Julias, daughter and granddaughter, contaminated with every kind of crime.'

The description of fate catching Augustus unawares and when he is at his happiest (laetum...atque fidentem) is, I suggest, deliberately evocative of Herodotus' Croesus narrative and its lesson that for all a man's wealth and power, fate will find a way of having the last word. Suetonius presents this series of events as a single episode, in which Augustus' hopes for his children are cruelly dashed to the extent that he wishes they had never been born at all. In Herodotus' account, Croesus' hubris similarly costs him the life of his dear son Atys (Htd. 34-5), but at least in that story Croesus is able to honour his son with a proper funeral and place his body in a tomb, and Herodotus' description of this provides closure 
to that tragic tale. In contrast, Suetonius' biography will end with Augustus' command that his daughter and granddaughter never be allowed a place in his family tomb (Aug. 101.3). Augustus' heart-broken response to the fate of the Julias - to regret utterly the whole idea of marriage and children that he had been so full of at Aug. 34 - takes us back to that earlier passage as well, so that this 'episode' represents the failure of that aspiration too, as well as his aspirations for his family. In both Aug. 34 and Aug. 61-5, Augustus is represented not so much as a hypocrite brazenly forcing legal restrictions on his subjects that he has no intention of living by himself, but as a man betrayed by fate, unable to achieve his aspirations, disappointed in his attempts to shape the future.

\section{Expectation, in hindsight}

The phrase 'disappointed expectation' is used by Paul Plass to describe the pattern found in several of Suetonius' biographies, where Suetonius structures his material so that the good deeds of an emperor's life precede his descent into depravity. In those cases the expectation in question is that of the emperor's subjects, hopeful at the start of the reign, subsequently disillusioned when the emperor reveals his true colours. ${ }^{32}$ In the case of Augustus' life, it is not the hopes of his subjects that are dashed, rather the aspirations of the man himself; nevertheless the same structure of hope followed by disappointment pertains. Such a structure enhances the pleasure of reading with foreknowledge and the frisson of hindsight. Tamsyn Barton has drawn our attention to the proleptic references to Nero's notorious crimes of murder, incest, and arson that are embedded in what look, on the face of it, like virtuous acts carried out early in his reign. ${ }^{33}$ Nero's dutiful behaviour following Claudius' death at Ner. 9 looks forward to 33.1 where he is shown to have been at least complicit in Claudius' murder, if not the murderer himself; Nero's honouring of his mother at Ner. 9, riding through the streets with her in a litter, anticipates his incest with her at 28.2; at 16.1 his building of platforms for fire-fighting anticipates his fire-starting at 38.1. The earlier, virtuous acts look deeply ironic in the face of events that take place later in the life and, given Nero's later reputation, with which Suetonius' contemporary readers would have been likely to be familiar, these early passages already create a prick of irony, whose full force is unleashed when the later passages are read and the hints are actualized. These ironizing structures can be found at work at the macro level too, over the whole twelve biographies, especially when it comes to positioning the life of Augustus, founder of the principate, with hindsight, within the context of the subsequent history of the institution. ${ }^{34}$ In Augustus' case we know, with Suetonian hindsight, roughly this: he has established a principate - a principate that has endured for a hundred years after his death; he has been deified; he has left an extraordinary legacy - material, political, legal and exemplary; yet, as we saw above, it has never been clear precisely how one should judge or interpret this legacy. The

\footnotetext{
32 Plass (1988) 19. Cf. the explicit and famous divisiones at Calig. 22.1 and Ner. 19.3, and the shift from dissimulation to overt vice in Tib. 42 and Dom. 10.

${ }^{33}$ Barton (1994) 50.

34 See n. 24 above.
} 
Augustus shows us a man who is busy trying to found a dynasty and an institution, and throughout the Augustus, a reader's awareness of the later history of the principate adds a frisson to Suetonius' account of its origins and development and Augustus' hopes for the future. ${ }^{35}$ Moreover, read as a whole, the lives trace the subsequent history of the principate, and deliberate allusions to the biography of Augustus in other Lives actualize the latent ironies of his aspirations. They show us the consequences for posterity of his actions, which are not always what he had in mind.

Suetonius uses hindsight to bring home to us Augustus' impotence in the face of destiny. Augustus' laws turn out to be counterproductive, the tragic results of his own family's strict upbringing are absolutely the opposite of what he intended, and his most enduring moral legacy is as a powerful paradigm of marriage-wrecking - the exemplum that got away. Suetonius' biography of Augustus is framed by references to two monuments associated with his birth and his death, with which Suetonius guides our interpretation of his life; this framing device, I think, supports my thesis that Suetonius wants us to see failure of sexual morality as a central motif. Both monuments - a shrine on the Palatine marking the spot where he was born, and the Mausoleum marking the spot where he was buried testify to Augustus' enduring legacy and the magnificence of his achievements, yet description of both is shot through with the reminder of his failure in this key area. The mention of Augustus' birth at Aug. 5 makes proleptic reference to his eventual death which will be treated at the end of the biography (99101) and to his deification, ${ }^{36}$ and also highlights the reader's knowledge that Augustus is destined to be remembered and revered in Suetonius' own present day (cf. nunc). The close link that is drawn between past and present draws the reader's attention, right from the start, to the position of hindsight from which this biography and all of Augustus' achievements are to be viewed. 'Augustus was born shortly before sunrise on the $9^{\text {th }}$ day before the Calends of October, when Cicero and C. Antonius were consuls, at the Oxheads in the Palatine, when he now has a shrine that was established sometime after he had died,' (natus est Augustus M. Tullio Cicero C. Antonio concc. VIIII. Kal. Octob. Paulo ante solis exortum, regione Palati ad Capita Bubula, ubi nunc sacrarium habet, aliquanto post quam excessit constitutum, Aug. 5). However, the neat little aetiological anecdote that follows, explaining the foundation of the shrine, summarizes the effect that hindsight can have on a reader's moral interpretation of Augustus' life, and introduces straightaway the theme of the failure of Augustus' aspirations regarding sexual morality and his inability to control his legacy:

\footnotetext{
35 On the deployment of hindsight to slightly different ends in Cassius Dio, see Kemezis (2007) 278: "when Augustus warns of the extinction of the noble republican gentes and their replacement by provincials and Greeks (56.7.5-6), the audience is meant to realize that both these events did subsequently happen, without leading to the ruin of the empire." And: “[Dio's] audience would have known that [the marriage laws] did not in fact result in greater fertility among the elite, which Dio claims was Augustus' objective."

36 Another example of the technique of ring composition that Benediktson has discussed in relation to the life of Galba in Benediktson (1996); see also Power in this volume on ring composition and especially the resonances between the opening and conclusion of Suet. Aug.
} 
Nam ut senatus actis continentur, cum C. Laetorius, adulescens patricii generis, in deprecanda grauiore adulterii poena praeter aetatem atque natales hoc quoque patribus conscriptis allegaret, esse possessorem ac uelut aedituum soli, quod primum Diuus Augustus nascens attigisset, peteretque donari quasi proprio suo ac peculiari deo, decretum est ut ea pars domus consecraretur, (Aug. 5).

'For, as recorded in the proceedings of the senate, when C. Laetorius, a young man of patrician birth, while pleading against a more serious punishment for adultery on grounds of his age and his rank, claimed this too: that he was the occupier and as it were guardian of the ground that was the first that the divine Augustus had touched as he was born, and when he sought to be pardoned as if on behalf of his own special god, it was decreed that this part of the house should be consecrated.'

Right from the start, a theme of Augustus' biography is that while the effects of his behaviour have been far-reaching, they have nevertheless not always been salutary. The shrine was established as a result of a young nobleman's trial for adultery, and he pled (successfully, one assumes) for a lighter sentence on the basis of his association with Augustus. Knowing, with hindsight, Augustus' efforts at moral reform and his extensive legislation designed precisely to curtail adultery among the Roman elite, his posthumous assistance to this adulterer is acutely ironic. This brief introductory passage already sets up the idea that in hindsight Augustus' moral legacy will be the very opposite of his intentions. Meanwhile the closing chapter of the biography (Aug. 101) is a lengthy and detailed account of the will that Augustus had drawn up sometime before his death, in which he attempts to secure his legacy and make careful provision for the future of the principate and the empire; this chapter characterizes Augustus as a responsible and caring leader with a great deal of foresight. ${ }^{37}$ Suetonius makes reference, just before the very end, to the Mausoleum that Augustus has built as the monument to his own life, and to the Res Gestae that he intends to set up at the entrance - Augustus' own attempt to control his legacy in bronze, documenting his achievements and offering himself as an exemplum for posterity. Nevertheless there is also an explicitly discordant note sounded here too: "He forbade the burial within his Mausoleum of his daughter Julia or his grand-daughter Julia, if anything should happen to them" (Iulias filiam neptemque, si quid iis accidisset, vetuit sepulcuro suo inferri, 101). This mournful provision in his will emphasizes once again, just before we take our leave of the biography, the fact that Augustus' legacy was not what he had hoped it would be, particularly in the areas of dynasty and sexual morality, where he strove so hard to be effective. Augustus failed to establish a healthy dynasty or a moral

\footnotetext{
${ }^{37}$ See Power in this volume on the significance of the endings of the biographies.*
} 
household.

\section{Conclusion: counter-imperial exemplarity}

These allusions to Augustus' pernicious moral legacy that frame his biography in Aug. 5 and Aug. 101, and pervade it through the passages discussed in this paper, offer a commentary on the relationship between fate and the individual. One cannot control fortuna, one cannot control one's legacy, and these are two important themes that run through all the Lives. The Augustus demonstrates, in addition, that despite Augustus' best efforts to establish an exemplary paradigm for the principate, one has no more control over one's exemplary influence than over any other aspect of the future. A man's life and a man's acts, once they are moulded and offered as exempla, are open to moral interpretation just as any traditional exemplum would be, ${ }^{38}$ and it is in no man's power to dictate what moral messages others will take from his life. The pervasive theme of the gap between Augustus' intentions and their outcomes is the framework for understanding Suetonius' take on imperial exemplarity. Citing morally inspiring exempla is always an attempt to exert control over the future; this is especially the case when one attempts to establish new exempla from one's own life or that of one's family, as Augustus does. In that respect it is perhaps an enterprise as hubristic as Croesus' claim to be the happiest man alive, and as futile as Croesus' attempt to prevent his son's predestined slaying with an iron weapon. Suetonius' story of Augustus demonstrates the high potential for failure of such exemplary endeavours. ${ }^{39}$ An exemplum that will be healthy enough to survive down the decades and down the centuries must be vividly memorable, and it also needs to be open to various interpretations, and able to endure being recast over and over again to make different moral and rhetorical points. By definition then, the author of a successful exemplum cannot control - or even necessarily foresee - how it will be read, understood, and utilized by later readers. ${ }^{40}$ Just like Augustus' aspirations, an exemplum's meaning is at the mercy of posterity, at least to the same extent as it has the capacity to influence posterity in its turn. Suetonius shows us an Augustus who has failed to grasp this limitation of exemplarity. Moreover, his exemplary inadequacy is thrown into relief by the theft-marriage exemplum that does flourish in Suetonius' pages, far beyond Augustus' control. The story of Augustus grabbing Livia has everything an exemplum needs. It is catchy; even the recurrent term abducere has a vivid narrative force to it, and the association with stereotypes about the behaviour of tyrants found in invective, as well as with the rape motif familiar from both Greek and Roman myth, make it immediately memorable. The heavy pregnancy is a vivid touch. The other vivid scenario of a respectable woman hustled off for sex during a dinner party and emerging dishevelled and red-faced is so closely associated with Augustus' seizure of Livia in the

\footnotetext{
38 On the flexibility of meaning in traditional exempla see further Chaplin (2000), Roller (2004), Langlands (2008).

${ }^{39}$ For a discussion of Augustus' inability to control how his exemplum will be interpreted by posterity see Lowrie (2007); she ends with the mention of Mussolini's unforeseen appropriation of Augustus as a model.

${ }^{40}$ Ibid. with reference also to Vell. Pat. 2.126.4.
} 
tradition as to enhance the latter's memorableness. ${ }^{41}$ It is also open to interpretation: Caligula cheekily cites it as a quasi-legal precedent, a rhetorical means of justifying his own immoral behaviour, but in doing so he also gestures to the inspirational qualities that are evident in the life of Domitian. The story - and it is a story, rather than a frigid description of virtue, like some of the imperial attempts at exemplarity - might be read as an exemplum of the emperor's ability to live beyond the law and to help himself to whatever he likes, and that will inevitably look like a different kind of moral message depending on the reader.

Suetonius' Augustus, as I have shown, questions Augustus' ability to shape the future as he would have wished. Suetonius shows that instead imperial exempla can have a wicked life of their own, countering the attempts of Augustus and subsequent emperors to stake their claim to beneficial exemplarity. Suetonius is attempting to regenerate some of the force of moral exemplarity, which has been dissipated and repressed by a century of imperial appropriation of the discourse. ${ }^{42}$ It is significant that the most strikingly successful exemplum in the Lives is one that entirely reverses the direction of imperial exemplarity; Otho's surprisingly heroic death is the result of his imitation of an anonymous soldier who killed himself in order to prove the veracity of the news he brought to Otho's camp (Otho $10.1)^{43}$. An emperor takes as his inspiration a soldier from the ranks, and the story has the distinct flavour of a traditional Republican exemplum, and a verve that we do not find in Augustus' imperial version. Otho and his soldier become exemplary by acting with true moral integrity, not by setting themselves up as exempla; it is perhaps the most morally uplifting passage that Suetonus ever writes. ${ }^{44} \mathrm{By}$ contrast, imperial exemplarity, embodied in Suetonius by the po-faced tableau of Germanicus and sons, lacks the memorable anecdotes and the arresting details of real exempla. ${ }^{45} \mathrm{Then}$, in his organization of the controversial material about Augustus and sexual morality, Suetonius resists the imperial trend towards exemplarity that is idealizing, prescriptive, and lacking in what Kraus describes as 'spectacular suggestiveness ${ }^{34}$; a complicated man has more to offer as an exemplum than an idealized portrait, and Suetonius suggests that we recoup the power of the flawed individual. ${ }^{47}$ Augustus' bad exemplum is allowed to run rampant through the lives, undoing his good work and creating more excitement than a litany of imperial virtues ever could.

\footnotetext{
${ }^{41}$ See Flory (1988) 344. She thinks that the second story (Aug. 70) is actually the result of Antony's spin on the marriage banquet of Augustus and Livia, and that Caligula's banquet, described at Calig. 25.1 is Caligula's deliberate parody of Augustus.

42 Cf. Chaplin (2000) 194 for the effect of Augustus monopolizing the interpretation of the past and Kraus (2005).

${ }^{43}$ Cf. 10.2, 11 and 12.2 for his exemplary death and the responses to it.

${ }^{44}$ The story is told by Tacitus (Hist. xx) and Plutarch (Otho) as well, but without the same focus on exemplarity and moral redemption.

45 See Roller (2004) for importance of visual details for a memorable exemplum.

${ }^{46}$ Kraus (2005) 188, and see above for full quotation.

${ }^{47}$ Cf Turpin (2008) 375-6 on Arrian's Alexander. See also Langlands (2008) for the power that controversy lends to an exemplum.
} 


\section{Bibliography:}

Baldwin, Barry (1983) Suetonius (Amsterdam).

Barton, Tamsyn (1994), 'The inventio of Nero: Suetonius', in Jas Elsner and Jamie Masters (eds.) Reflections of Nero (London): 48-63.

Bauman, R. (1982) 'The Resumé of Legislation in Suetonius', ZRG 99: 81-127.

Benediktson, D. T. (1996), 'Structure and Fate in Suetonius' Life of Galba', Classical Journal 92: 167-73.

Bradley, K. (2010), 'The exemplary Pliny', in C. Deroux (ed.) Studies in Latin Literature and Roman History XV (Brussells): 384-422.

Chaplin, Jane D. (2000), Livy's Exemplary History (Oxford).

Cooley, Alison (1998), 'The moralising message of the Senatus Consultum de Cn. Pisone Patre' Greece and Rome xlv: 199-212.

Cooley, Alison (2009) Res gestae divi Augusti : text, translation, and commentary (Cambridge).

Davis, P.J. (1999), “'Since my part has been played well”: conflicting evaluations of Augustus', Ramus 28: $1-15$.

Edwards, Catharine (1993), The Politics of Immorality (Cambridge).

Evans, E. C., (1969): "Physiognomics in the Ancient World" Transactions of the American Philosophical Society 59: 1-101

Flory, Marleen B. (1988), 'Abducta Neroni uxor: The Historiographical Tradition on the Marriage of Octavian and Livia', Transactions of the American Philological Association 118: 343-359.

Grethlein, Jonas (2009), 'Philosophical and Structuralist Narratologies - Worlds Apart?', in J. Grethlein and Antonios Rengakos (eds.) Narratology and Interpretation: the content of narrative form in ancient literature (Berlin): 153-174.

Harrison, T., (2000) Divinity and History: The Religion of Herodotus (Oxford)

Henderson, John (2011), 'Down the Pan: historical exemplarity in the Panegyricus', in Paul Roche (ed.) Pliny's Praise: The Panegyricus in the Roman World (Cambridge): 142-174.

Kemezis, Adam (2007), 'Augustus the Ironic Paradigm: Cassius Dio's Portrayal of the Lex Julia and Lex Papia Poppaea', Phoenix 61: 270-85.

Kraus, C. (2005), 'From exemplum to exemplar? Writing history around the emperor in Imperial Rome', in J. C Edmondson, Steve Mason and J. B. Rives (eds.) Flavius Josephus and Flavian Rome (Oxford): 181-200.

Langlands, Rebecca (2006), Sexual Morality in Ancient Rome (Cambridge).

Langlands, Rebecca (2008), "Reading for the Moral" in Valerius Maximus: the case of Severitas', in Proceedings of the Cambridge Philological Society/Cambridge Classical Journal 54: 160-187.

Lowrie, Michèle (2007), 'Making an exemplum of yourself: Cicero and Augustus', in S.J. Heyworth (ed., with P.G. Fowler and S.J. Harrison), Classical constructions: papers in memory of Don Fowler, classicist and epicurean (Oxford): 91-113.

McGinn, Thomas A. (1998), Prostitution, Sexuality and the Law in Ancient Rome (New York).

Plass, Paul (1988), Wit and the Writing of History: the rhetoric of historiography in imperial Rome (Madison, Wis.).

Roller, Matthew B. (2004), 'Exemplarity in Roman Culture: the cases of Horatius Cocles and Cloelia', Classical Philology 99: 1-56.

Treggiari, S. (1991), Iusti Coniuges. Roman Marriage from the Time of Cicero to the time of Ulpian. Oxford.

Turpin, William (2008), 'Tacitus, Stoic exempla, and the praecipuum munus annalium', Classical Antiquity 27: 359-404.

Vinson, Martha P. (1989), 'Domitia Longina, Julia Titi, and the Literary Tradition', Historia 38: 431-450.

Wallace-Hadrill A., (1981), 'Family and Inheritance in the Augustan Marriage Laws', PCPhS 27: 58-80

Wardle, David (1994), Suetonius' Life of Caligula - a Commentary (Brussels).

Wardle, David (2007), 'A perfect send-off: Suetonius and the dying Art of Augustus (Suet. Aug. 99)', Mnemosyne 60: 443-463. 
